\title{
Authorship and the popular song
}

\section{Keith Negus}

Essay published in Music and Letters

Vol 93 No 4, 2011, 607-629. ISSN 0027-4224.

Final Version submitted 18 July 2011.

For the published version please visit https://academic.oup.com/ml/articleabstract/92/4/607/1141626 


\section{Authorship and the popular song}

Within the broad field of musicology and music criticism the author as creative originator and authority remains a central figure. Whether a critic is concerned with the canonical greats of Western art music or an emerging canon of popular musicians; whether a scholar's focus is critical, formally analytical or biographical - repertoire is located within a clear framework of assumptions about the individual authorial self.

An obvious response might be; why not? There are usually objectively identifiable individuals, collaborators or groups of people that are legally recognised, economically rewarded and socially recognised as the creators of a musical work (whether a song, a string quartet or film soundtrack). In addition, there is considerable evidence to suggest that music listeners interpret and understand songs or symphonies as motivated, authored and intentionally created - not necessarily in a mystical or magical manner, but according to the techniques and mechanisms of composition that are routinely discussed within and presented by the press and broadcast media, along with information about musical activities acquired over the internet.

The evidence to support the widespread vernacular valuing of authorship in popular music can be found in journalism, discussions amongst fans on internet fora and a plethora of blogs. Recognition of authorship is also apparent in scholarship that focuses on individual artists and their songs (the texts within which authorial intent is located or implied), whether journal articles or book length studies. ${ }^{1}$ Even when the issue is approached cautiously, from the stance of a critical musicology informed by cultural studies scepticism, the notion of authorship seems unavoidable, exemplified in Richard Middleton's analysis of how the Eurythmics created their music, imagery and performances. Although arguing that the authorship of Annie Lennox and Dave Stewart entailed working with styles that 'carry their own discursive baggage', and manifested an ironic, knowing use of signs and existing pop elements, the authors are central to Middleton's analysis - albeit as self-consciously, postmodernist 'authors' (deliberately in inverted commas) aware of and refusing the romantic 'mystifications of traditional notions of authorship'. ${ }^{2}$

Hence, whether in fan talk, journalism or academic writing, authorship is routinely attributed to and heard in a song's performance and read from lyrics. This is not to presuppose a consensus, nor coherence to the interpretation of authorship. One of the reasons fans come together to discuss songs (whether in person before and after concerts; or in virtual fora on the internet; or as academics at scholarly conferences) is for the pleasures of disagreeing and even fiercely arguing about the way authors are

1 See for example various essays in Richard Middleton (ed) Reading Pop: Approaches to Textual Analysis in Popular Music (Oxford University Press, 2000) and the series published by Equinox, Icons of Pop Music.

2 Richard Middleton 'Authorship, Gender and the Construction of Meaning in the Eurythmics' Hit Recordings' Cultural Studies, 9 (3), 1995, 465-485, 468-9. The phrase 'the mystifications of traditional notions of authorship' is deployed in a largely rhetorical manner, without clarification, substantiation or illustration. 
implicated in the meanings of songs, the stories and contexts that inform songs, and the wider social significance of songs. ${ }^{3}$

A common point of debate concerns the attribution of authorship, an issue that has been prevalent in the history of western art music. ${ }^{4}$ In the study of popular music the crediting and acknowledging of authorship has usually been framed and given focus by legal disputes about copyright and plagiarism. Yet, during such disputes it is rare to find the resultant critical reflections about social influence moving outwards and connecting with discussions about authorship in other disciplines (music criticism and music analysis so often reduce the issues to stylistic influence, or the similarities between two texts, ignoring broader contextual issues). In the first part of this essay I shall sketch the contrasting agendas presented by and implicit within the musicology and sociology of authorship. I will then argue that insights from musicology and sociology can be brought into dialogue with ideas drawn from the study of literature and narrative, and suggest that this allows for disaggregating or 'unbundling' different facets of an author's identity. I aim to propose ways of developing a musicology of pop song authorship, and point to some opportunities for interdisciplinary dialogues between musicology, sociology and the study of fictional narrative.

\section{From author to auteur to absence}

When George Harrison went to court in an effort to defend the similarities between 'My Sweet Lord' (1970) and 'He's So Fine' (1962), a song credited to Ronald Mack, he was found guilty of 'subconsciously' copying The Chiffons' recording of this song and was required to formally offer financial recompense..$^{5}$ The charge of 'subconscious' copying allowed Harrison to retain his integrity as a composer - he had not deliberately copied the song, and the charge was compatible with the widely acknowledged influence of early 1960s girl groups on the Beatles' songwriting. ${ }^{6}$ In contrast, John Lennon quite consciously used lyrics, melodic phrases and a riff from Chuck Berry's 'You Can't Catch Me' (1956) in composing 'Come Together' (1969). Lennon had drawn much inspiration from Berry and used lyrics and musical phrases in a number of other songs (many motifs that had been 'borrowed' by Berry himself from previous songs). ${ }^{7}$ Unlike Harrison, Lennon reached an out of court settlement that entailed payment and an agreement to record three songs

3 Various sites on the internet provide a window into the ways that fans can passionately and polemically debate the meaning of songs. See for example www.songmeanings.net ${ }^{4}$ A well known example being the novelty Toy Symphony, often played at Christmas. For many years this was attributed to Haydn, then to Mozart's father Leopold, although now doubts remain as to its authorship.

5 The case continued, and - somewhat ironically - later resulted in Harrison acquiring the company Bright Tunes which owned the copyright to 'He's So Fine'. See Peter Doggett You Never Give Me Your Money: The Battle for the Soul of the Beatles (London; Vintage, 2010). 6 Barbara Bradby 'She Told Me What to Say: The Beatles and Girl-Group Discourse', Popular Music and Society, Vol 28 No 3, (2005) pp359-390.

7 As Kevin Howlett wrote in the liner notes to the double CD The Beatles Live At The BBC 'The choice of material in these and other programmes clearly reveals the artist who had inspired the group. Chuck Berry heads the list with nine BBC cover version', The Beatles Radio Sessions 1962-65, p9, Apple Records, 1994. For a discussion of the influences on Chuck Berry's songwriting see Bruce Pegg Brown Eyed Handsome Man, The Life and Hard Times of Chuck Berry (Routledge, New York, 2002). 
owned by Morris Levy (the rights holder). Lennon's subsequent version of the Chuck Berry song appeared on his album Rock'n'Roll (1975), an arrangement and recording which ironically referred to the instrumentation and ambience of 'Come Together' (acknowledging the similarities between the two songs, yet marking the contrasts between the recordings). The out of court settlement meant that Lennon also retained his integrity as a songwriter. He was not obliged to formally acknowledge Berry's 'contribution', as Brian Wilson of the Beach Boys was required to do with the song 'Surfin' USA' (1963) which became a Chuck Berry composition, despite Wilson's lyrics. ${ }^{8}$ Although 'Come Together' was credited as a Lennon-McCartney composition when released, Paul McCartney was not involved in the dispute, an overt acknowledgment that it was 'John's song', allowing McCartney to categorically retain his creative integrity. These are just two examples from amongst many other cases, settled out of court, which have entailed a similar 'deal' in which no formal compositional authorial credit has been conceded even though financial recompose has taken place: Deals that allow songwriters to retain their authorial integrity as originators. ${ }^{9}$

Such disputes illustrate Will Straw's observation that the 'problem of authorship in popular music has normally been reduced to one of the relationship between songwriter and song. ${ }^{\prime 0}$ It is the composer and lyricist or the songwriters that are routinely valued as the authors, and this underpins the legal disputes referred to above. This point is further illustrated in Rob Bowman's study of the contrasting melodic, harmonic and timbral qualities of different performances of Irving King's and Harry Woods's composition 'Try A Little Tenderness' (1932) as recorded by Bing Crosby (1933), Aretha Franklin (1962), Sam Cooke (1964) and Otis Redding (1966). It is also vividly apparent in Tom Perchard's study of the improvisations of Thelonious Monk in which, regardless of how little resemblance there is between Monk's performances (1966) and 'Lulu's Back in Town' (1935) by Al Dubin and Harry Warren, the 'original' composers of what more or less amounts to a chord sequence are legally credited as the authors. ${ }^{11}$

Bowman's and Perchard's studies are indicative of a significant musicological response to uncritically received romantic notions of authorship, and demonstrate the influence of popular music studies and jazz scholarship in shifting the focus from the work to the performance. Or, more tentatively, in the words of Nicholas Cook, 'musicology's faltering

\footnotetext{
8 See Pegg Brown Eyed Handsome Man 162-3.

9 An interesting case is that of Steely Dan songwriters Walter Becker and Donald Fagen who reached an out of court settlement with Keith Jarrett over similarities between their 'Gaucho' (1980) and Jarrett's 'Long as You Know You're Living Yours' (1974). Initial unsubstantiated reports suggested that this entailed financial recompense whilst allowing Becker and Fagen to retain songwriting credit. However, in subsequent publications (most notably sheet music songbooks), Jarrett has been receiving a songwriting credit. A case that is perhaps illustrative of three songwriters struggling to assert their creative integrity.

10 Will Straw 'Authorship' in Bruce Horner and Thomas Swiss (eds) Key Terms in Popular Music and Culture ( Oxford, Blackwell, 1999), 199-208, 201.

11 Rob Bowman 'The determining role of performance in the articulation of meaning: the case of "Try a Little Tenderness"', in Allan Moore (ed) Analyzing Popular Music, (Cambridge University Press, 2003). Tom Perchard 'Thelonious Monk Meets the French Critics: Art and

Entertainment, Improvisation and its Simulacrum'. Jazz Perspectives, 5, 1, 2011.
} 
advance towards a performance studies paradigm' has been an attempt to challenge the centrality of the 'musical work' and a movement away from 'a conceptual paradigm that constructs the process as subordinate to the product'. ${ }^{12}$ Drawing from theatre studies and ethnomusicology, Cook has argued that notated musical works should be treated as 'scripts' that are open to interpretation and re-interpretation. Although illustrated largely with reference to the scores of western art music, Cook's article is indicative of attempts to challenge composer-centred musicology - to think about the relationship between a composition (whether a pop song or symphony) and the performances of that composition. Cook is sceptical about a strand of performance theory that would do away with the 'work' and merely invert the previous paradigm, and convincingly insists that musical performances are always of something (and this something involves an author).

Although performance has been increasingly acknowledged as a theoretical issue, and despite the critical recognition accorded to performers (whether improvising jazz musicians, pre-pop crooners or girl groups), it is the originating author (the composing songwriter) that holds a privileged place in the economic and cultural valuing of creativity (rights revenue is allocated to the song 'writer' and not the interpreter). Certainly, in the critical reception of pop music since the 1960s, there has been a valuing of the performer who creates their own material - Lennon, Bob Dylan, Stevie Wonder, Tori Amos or P J Harvey - authenticated as a form of direct expression, rather than the performer who provides an interpretation or rendition of a song. ${ }^{13}$ At the same time, an enduring legacy from the pre-rock era has seen value accorded to songwriters able to compose for others in such a way as to contribute to the personal and stylistic identity of a singer, whether Burt Bacharach and Hal David writing for Dionne Warwick or the Motown Records team of Eddie Holland, Lamont Dozier and Brian Holland whose songs helped define the musical identities of The Supremes, Four Tops, and Martha and the Vandellas.

If Lennon and Harrison are two of the most prominent popular songwriters to retain authorial integrity despite obvious 'influences', this was in contrast to the ambiguities that accompanied the critical reception accorded to Madonna during the 1980s. Much commentary about Madonna at the time focused entirely on her visual image, and neglected her music and musicianship. In one of the first musicological studies of Madonna, Susan McClary located such an approach within the context of social, cultural and musical gender divisions, arguing against those at the time who had neglected Madonna as musician. The following comments that prefaced McClary's musical analysis allow me to begin opening up a series of issues that I will be addressing throughout this section, moving increasingly outwards from the individual to social and cultural context:

I will be writing of Madonna in a way that assigns considerable credit and responsibility to her as creator of texts. To be sure, the products ascribed to Madonna are the result of complex collaborative processes involving the input of co-writers, co-producers, studio musicians, video directors, technicians, marketing specialists, and so forth. As is the case in most pop, there is no single originary genius for this music. Yet the testimonies of co-workers and interviewers indicate

12 Nicholas Cook 'Between Process and Product: Music and/as Performance' Music Theory Online 7, 2, (2001), 6/2.

13 For a discussion of debates about the attribution of authenticity in popular music see Allan Moore 'Authenticity as Authentication', Popular Music, 21, 2, 209-23 (2002). 
that Madonna is very much in control of almost every dimension of her media persona and her career. Even though certain components of songs or videos are contributed by other artists, she has won and fiercely maintains the right to decide finally what will be released under her name. It may be that Madonna is best understood as head of a corporation that produces images of self-representation, rather than as the spontaneous, 'authentic' artist of rock mythology. But a puppet she's not. ${ }^{14}$

Many subsequent writers have taken up McClary's call, and a significant body of scholarship has endorsed and extended this approach to Madonna's agency. Yet, Madonna's authorship of songs has still been marginalised even as feminist scholars have stressed her independence and editorial power, and argued for Madonna's control over her commodification and self-representation. The valuing of Madonna's authority as producer of signs has not necessarily contributed to the recognition of her songwriting. For example, in Sheila Whiteley's study of women musicians she provides detailed case studies of Joni Mitchell, Annie Lennox, k.d. lang, Tracy Chapman and Tori Amos with fine attention to the details of timbre, melody, harmony and vocal technique. Yet, her account of Madonna focuses almost entirely on her videos, with very little attention to musical content. ${ }^{15}$

This scepticism about Madonna as creative musician has also been apparent in interviews, a conspicuous example being one conducted by songwriter Paul Zollo in which he prefaced his questions to the singer by saying: 'It's interesting to learn that you have written so many of your own songs', to which Madonna responded:

It's the image that gets in the way. What am I supposed to do? The information is on the label. If they don't read it, that's not my problem. I'm not going to put a sticker on the outside of the album that says "Listen - I wrote these songs!" You know, they pay attention to what they want to pay attention to. ${ }^{16}$

In focusing on Madonna as a musician, and emphasising her co-writing and coproduction, McClary developed an argument about her authorial authority that was informed by auteur theory. Auteur theory developed in film criticism initially in France during the 1950s and 1960s and suggested that despite (and also because) filmmaking is dependent on collaborations (whether consensual or conflict ridden) it is the director who imposes his or her will and vision upon the film. Hence, the practice of filmmaking and the manifest and latent content of movies can be treated as motivated and 'authored' by the director, and be recognised as an Alfred Hitchcock or Spike Lee or Sally Potter film - a common way that movies are discussed (regardless of the disputes about the

14 Susan McClary Feminine Endings, Music, Gender and Sexuality (Minnesota; University of Minnesota Press, 1991) 149.

15 Sheila Whiteley Women and Popular Music: Sexuality, Identity and Subjectivity (London: Routledge, 2000). For examples of the emphasis on Madonna as subcultural icon rather than musician see also Santiago Fouz Hernandez and Freya Jarmen-Ivens Madonna's Drowned Worlds: New Approaches to Her Cultural Transformations 1983-2003 (Aldershot: Ashgate, 2004); Cathy Schwichtenberg The Madonna Connection: Representational Politics, Subculural Identities and Cultural Theory (Boulder: Westview Press, 1993).

16 Paul Zollo Songwriters on Songwriting, Fourth Edition, (Cambridge MA, Da Capo Press, 2003), 616. 
application of this term in film studies). ${ }^{17}$ Madonna is not the only popular musician to be portrayed as auteur. Ron Moy has characterised Kate Bush as auteur and argued that this concept allows for understanding how female songwriters (he also refers to Madonna and Björk) negotiate and impose their will - authoring sounds and imagery, regardless of the contribution of named male directors, producers, collaborators, engineers, musicians and 'mentors' (such as Peter Gabriel and Richard Burgess, in the case of Kate Bush). ${ }^{18}$

Yet, back in the 1980s Kate Bush was credited as a creative songwriter in a far more direct, traditional and individual manner than Madonna (as Moy acknowledges). And, despite the recognition of Madonna's auteurial influence, reservations remained. As Will Straw observed, highlighting the ironies of influence mediated through the legal framework of copyright:

In conceiving many of her performances, Madonna may have drawn on the music, dress, and postures of drag subcultures, but there is no widespread sense that these things were the legal possessions of those subcultures or that her borrowing was an act of theft. However, when these elements become part of Madonna's own legally protected performances, their subsequent borrowing by others may be judged as an act of plagiarism or direct imitation. ${ }^{19}$

Even when analysing how authorship is constructed through marketing and publicity, as is emphasized by Laura Ahonen in an ethnomusicological study of how authorship is represented and commercially mediated, all signs still lead back to an identifiable author; whether the individual singer-songwriter (such as Tori Amos) or the band that give all members a credit as 'collective' authors regardless of how the song was created (such as U2 or REM), or the author of a more broadly defined bundle of musical texts (Madonna). Ahonen suggests that the rise of the DJ has led to a notion of 'diffused authorship'. But, only to a small degree. Sampling has not challenged the notion of authorship, just involved the need to credit a range of authors, with the DJ assuming (once more) the 'auteur' role (an obvious example is the authorial credit given to Fat Boy Slim for his quite transparent use of other musical recordings). ${ }^{20}$

17 See John Caughie Theories of Authorship (British Film Institute/ Routledge: London, 1981) - despite its general title it is concerned with debates about auteurship in the study of film.

18 Ron Moy Kate Bush and the Hounds of Love (Farnham: Ashgate, 2007), 72-88. The earliest application of auteur theory in the study of popular music can be found in Dave Laing Buddy Holly (London: Macmillan, 1971). See also Leland A. Poague's application of 'auteur' theory as a means of finding a unity across Bob Dylan's oeuvre, 'Dylan as Auteur: Theoretical Notes, and an Analysis of "Love Minus Zero/ No Limit"' The Journal of Popular Culture 8, 1, (1974).

19 Will Straw 'Authorship' in Bruce Horner and Thomas Swiss (eds) Key Terms in Popular Music and Culture (Oxford, Blackwell, 1999), 199-208, 201.

${ }^{20}$ Laura Ahonen Mediated Music Makers: Constructing Author Images in Popular Music, (Finnish Society for Ethnomusicology, 2007); Laura Ahonen Constructing Authorship in Popular Music: Artists, Media and Stardom (Saarbrücken, Germany: VDM Verlag Dr. Müller, 2008). 
The valuing of authorship is fundamental to music criticism and musicological explanation - the understanding of texts, and the stylistic practices through which texts have been produced. Yet, the issue remains under-interrogated. Its importance is apparent in the romantic notion of the great individual (still an influence), in the broadened sense of texts as authored through some notion of auteurial will, and in the shift towards performance studies (a performance of something, as Cook argues). Such perspectives are in stark contrast to the sociological critique of notions of authorship which seeks to deemphasise the individual, an approach epitomised by the influential writings of Howard Becker and Pierre Bourdieu.

Drawing from his experiences as a jazz piano player, Becker produced a series of essays during the 1970s culminating in the book Art Worlds in which he offered a challenge to the idea that art is produced by unique individuals working alone, arguing for 'art as collective action', and emphasising 'patterns of co-operation among people' rather 'than works themselves and those conventionally defined as creators. ${ }^{21}$ Becker drew the term 'art worlds' from its use in everyday conversation in the creative arts, and deployed it as a metaphor to signal the networks of people who co-operate according to a shared knowledge of conventions, and consensual routines: 'Art worlds consist of all the people whose activities are necessary to the production and characteristic works which that world, and perhaps others as well, define as art.'22

Becker's theory emphasises the characteristic features of the making of an artwork which are often not immediately apparent and acknowledged, such as the availability of materials, distribution systems and technologies (a piano, amplification or a concert hall). Above all he emphasises the taken for granted, internalised conventions that result in decisions to select certain scales and harmonies (and not others), or which determine the length of a performance (the three minute pop song). Conventions are enabling, they allow for artistic work to occur, for creative communication to take place; musicians can play together because they share knowledge of the conventions. But conventions can also be perceived as constraining. ${ }^{23}$ Furthermore, Becker stresses how the production of art simultaneously entails the production of reputations: 'All the co-operation which produces art works, then, also produces the reputations of works, makers, schools, genres and media.' ${ }^{24}$

Building upon Becker's arguments, Bourdieu developed a theory of the 'field of cultural production' as a challenge to what he characterised as the 'substantialist mode of thought' which foregrounds the unique individual. ${ }^{25}$ Bourdieu argued that the 'field of

\footnotetext{
21 See Howard Becker Art Worlds (Berkeley: University of California Press, 1982); 'Art Worlds and Social Types' American Behavioural Scientist 196 (1976) 703-; 'Art as Collective Action' American Sociological Review 396 (1974) 767-776.

22 Howard Becker Art Worlds (Berkeley: University of California Press, 1982), 34.

${ }^{23}$ For an extended discussion of this issue see 'Chapter 4 Conventions' in Keith Negus and Michael Pickering Creativity, Communication and Cultural Value (London: Sage, 2004).

${ }^{24}$ Howard Becker Art Worlds (Berkeley: University of California Press, 1982), 362.

25 Pierre Bourdieu The Field of Cultural Production (Cambridge: Polity Press, 2003). Bourdieu's and Becker's work informs Jason Toynbee use of the term 'social authorship' and the notion that an 'author stands at the centre of a radius of creativity ... the biggest advantage of treating popular music authorship in such a way is that it enables one to be
} 
cultural production' could be envisaged as a competitive arena occupied by artists, whether they be poets, novelists, painters or musicians, along with state and commercial institutions, and other intermediaries. He stressed the sociological struggles over position, power and prestige that - far from simply underpinning the field - are intrinsic to the creation of artworks and artistic reputations. Whilst his model was informed by various sociological and anthropological precedents, it also resonated with a long standing argument about the recorded music industry; if an individual wants to be recognised and rewarded as a musician (or visual artist or novelist) then their chances may be shaped by a certain talent and marketable repertoire, but the material chances of realising such possibilities will be determined more by conflicts over position, a struggle to define what constitutes legitimate artistic practice, rather than any consensually acknowledged ability. Like Becker, Bourdieu argued that the field of cultural production is not only characterised by a struggle to get creative work produced, but to have it critically recognised. Such struggles may involve authors, critics, commercial enterprises and academics - all attempting to influence the ideas through which any author's work is valued and appreciated.

If musicological accounts provide hints and brief glimpses of such struggles, the sociological approach, after Bourdieu and Becker, seeks to use such tensions to shift the argument, maintaining that to understand cultural production we should not look towards the life of the individual. Bourdieu was emphatic; 'the essential explanation lies outside of them in the objective relations which constitute the field. ${ }^{26}$ For Peter Martin a sociological approach must be detached from the interpretation of textual meaning, aesthetic judgement and the creativity of musicians; 'we must remain indifferent to the arguments of musicians, critics, and so on in their various debates and disputes.' 27

Such a sociological critique of authorship might allow for contrasting perspectives on the songwriters referred to above. For example, it would be possible to argue that neither Chuck Berry nor John Lennon should be isolated and elevated as exemplary individuals, but instead should be socially located within distinct folk, blues and rock'n'roll traditions, along with the fields of commercial music production that are framed by notions of individual ownership and the powerful ideological force of copyright law which protects a model of privatised intellectual property. ${ }^{28}$ What so often appears as the context and backdrop to a musician's rise to prominence and critical recognition (the sociological conditions which the individual manages to musicologically transcend) should be emphasised. In Bourdieu's terms, the creative and cultural recognition of authors should be viewed as socially constituted rather than the result of talent or genius. ${ }^{29}$

sceptical about grand claims to creative inspiration' Making Popular Music: Musicians, Creativity and Institutions (Arnold; London, 2000).

${ }^{26}$ Bourdieu Field of Cultural Production 30.

27 Peter J. Martin, Sounds and Society: Themes in the Sociology of Music (Manchester University Press, 1995), 12.

28 The profound influence of legal definitions of authorship are discussed and illustrated in Jane Gaines Contested Culture: The Image, the Voice and the Law (Chapel Hill: University of North Carolina Press, 1991).

${ }^{29}$ So, for example, sociologist Richard Peterson made the following comments when explaining the emergence of rock'n'roll: 'The reader may have noted that one important occupational type seems to be missing, the creative artist, the genius. Some performers involved with the advent of rock including Chuck Berry, Little Richard, and Elvis Presley 
Insightful as such an approach might be in illuminating the social conditions within which any songwriter might received economic reward and critical recognition, I remain sceptical of the sociological approach due to the way it simply reverses the imbalanced account of the relationship between individual creativity and social context. This is apparent when Bourdieu argues that 'position takings arise quasi mechanically - that is almost incidentally of the agents consciousness and wills.' ${ }^{30}$ The specific qualities of songs and the way they resonate (and do not resonate) with other musicians and large numbers listeners is evaded or is dissolved into a field of battles for power and prestige; with artistic reputations explained solely in terms of social struggles over ideas and resources. Whilst there is certainly a value in advocating such an approach, particularly to contest naïve notions of genius, as I have argued elsewhere in a book co-authored with Michael Pickering:

In cultural studies and the sociology of culture, genius is often critiqued, or dismissed entirely, because of an overriding concern to reconceive creativity as a more general phenomenon than that advanced in conventional aesthetic canons. While this is self-evidently laudable, it has created a huge obstacle to thinking about exceptionality in cultural creativity. It is one thing to argue against elitism but quite another to attribute creativity, equally, to everyone. This is misleading - flattening the concept into insignificance. ${ }^{31}$

Whilst only a few songwriters may receive the epithet genius, it is this issue that is at the heart of the tensions and disputes between musicology and sociology. Music criticism insists that there is something that makes music and musicians special; that there is something more than the field of cultural production can offer. The unique qualities of Miles Davis or the Beatles or Björk cannot be sociologised away. Anyone with knowledge of these musicians knows that they did not create music in isolation, nor in a mystical manner. There is nothing very mysterious about recent serious musical studies of the way these artists created their work. ${ }^{32}$ No matter how much context and collaboration is added to the picture, their authorship will not go away and is central to any understanding of their music and its influence.

In certain respects the musicology of the popular song is still grappling with a question that has been prevalent in the study of fictional narrative and literature, and which - in terms of written records in the western tradition - goes back to Plato. It is that deceptively simple question; what is an author? It implies two further questions: What

have recently been called geniuses. At the time, however, they were not so designated, nor did they act the part'. 'Why 1955? Explaining the Advent of Rock Music', Popular Music 9 (1990), 114. Tia DeNora has applied Bourdieu's approach to a study of the 'social construction' of Beethoven's 'genius' see Beethoven and the Construction of Genius (Berkley; Univ of California Press, 1997). For a critique of this see Peter Kivy The Possessor and the Possessed, Handel, Mozart, Beethoven and the idea of Musical Genius (Yale University Press: New Haven, 2001).

${ }^{30}$ Bourdieu Field of Cultural Production 59.

31 Keith Negus and Michael Pickering Creativity, Communication and Cultural Value, 149

${ }^{32}$ See for example Walter Everett The Beatles as Musicians: the Quarry Men Through Rubber Soul (Oxford University Press, 2001); Nicola Dibben Björk (Equinox; London, 2009); Ian Carr Miles Davis, The Definitive Biography (London, Harper Collins, 1999). 
does an author do? What is entailed in the process of authoring? Over a long period of time, those debating these questions have dealt with concepts of originality, representation, creativity, and communication along with notions of the self, subject and genius. ${ }^{33}$ In the contemporary study of popular music, these questions permeate discussions of individual musicians (whether Dylan or Madonna), and can be found routinely posited in interviews with songwriters and interrogated in academic studies. In this way, a long tradition of writing about poetry and fiction feeds into the study of the popular song (whether acknowledged or not).

The sociological critique takes off from a later point on this trajectory of debate about authorship, and dovetails into an emphatic rejection of the author as the point of authority for all attributions of intentionality, expression and meaning. It is no coincidence that Bourdieu's theory of the field of cultural production was being developed in articles published from 1968, the year after his French compatriot Roland Barthes first published a critical and conceptual execution of the author.

As is widely known, the 'death of the author' was a phrase introduced in a brief essay by Barthes and offered an overt challenge to the idea that the meaning of any text can be fixed and understood in relation to the figure of the author. Contemporaneous with sociologists wishing to transfer attention to broader social conditions and influences, Barthes argued for a shift in processes of interpretation; a move from an authoritative text to inter-textual reference points; from author's intentions to reader's insights. Whilst Barthes work is significant in raising critical questions about the apparent unity of any authorial identity, in practice the idea was often applied in such a way that the reader now became the 'author' of the text. If the meaning of any text is not fixed but forever open to various interpretations, then it is no longer the originator who should be held up as the authority on this matter. The interpretations of the viewer, reader, and listener should be integral to how artworks are understood.

Despite the apparently democratising and pluralistic sentiments that have often accompanied the application of this new orthodoxy, the death of the author and the apparent 'rise of the reader' has proved to be less about revealing and supporting the real responses of ordinary readers, but instead a means of elevating the prominent interpretations of the professional critic and scholar. Strikingly, as Seán Burke has argued, in denying the author - in seeking to remove the author from the discussion - such an approach merely emphasizes the author's presence; the author acquires a greater significance due to her or his (apparent) absence. Burke also highlights the contrast between a theory that sought to eradicate the author from discussion of texts, and widespread public beliefs and practices whereby texts are heard, seen and read as authored and authors are integral to how a text is discussed and interpreted. ${ }^{34}$

A beleaguered author emerges from the arguments so far; clinging to their creative integrity in the face of accusations of personal plagiarism, passive complicity in their social construction and commercial mediation, wilful conceit in struggles for power and prestige. This is not the naïve, mystical great individual that is the object of sociological scepticism and unease amongst critical musicologists. It is an author - and an idea of the author - that is more

33 See Seán Burke Authorship: From Plato to the Postmodern (Edinburgh University Press, 1995).

34 Seán Burke The Death and Return of the Author: Criticism and Subjectivity in Barthes, Foucault and Derrida, Second Edition (Edinburgh University Press, 1998). 
obviously mediated, constructed and contested. It is neither the great individual implied in a certain trajectory of music criticism and musicology, nor is it the enigmatic phantom conjured up by social forces, fields of production and battles for resources and prestige. It is a far more tentative author, an author that I believe can be illuminated and animated by the application of ideas drawn from the study of narrative, along with insights from study of songs and stardom.

\section{Between the real author and the public persona: negotiating authorship in the popular song}

In his influential book The Rhetoric of Fiction Wayne C Booth argued that a distinction could be made between the 'real author' of any text and its 'implied author', terms that have been adopted widely in the study of fictional narrative. ${ }^{35}$ What any audience member, critic or scholar knows of the 'real' author of a narrative may be informed by extensive information acquired through first hand experience, face to face encounter or it may be based upon very limited knowledge accrued from texts or media and gossip. The real author could be identifiable as one person (a novelist, poet or songwriter) or it might be many people, as in the making of a film, the continual changes and additions to a folk ballad passed on orally over many years, or a track created by a songwriting/ production team. If the real author is one person, he or she may hold incoherent or inconsistent views (evidenced in public statements or in interviews) or we may be aware that this person has changed their beliefs since creating a particular fictional or factual work. If the real author is more than one person - the members of a rock band and their producer, the writers of a rap track, for example - it might be implausible to reduce such contributions to any one set of authorial attributes, beliefs and experiences.

Booth's use of this term and its adoption in narratology does not presuppose a transcendent, unified and knowable (and coherently self knowledgeable individual). Instead, it places the author in inverted commas, or in brackets, or simply to one side, as slightly unknowable. It is certainly not incompatible with the claim that a real author's identity may be constituted and realised through a series of position takings in the field of cultural production. It attempts to lightly undermine any reification of authorship by arguing that the real author can be differentiated from the 'implied author', which $\mathrm{H}$ Porter Abbot summarises as 'that sensibility (that combination of feeling, intelligence, knowledge, and opinion) that "accounts for" the narrative.' 36 Abbott suggests that the real author is generally knowable only as a fact, but not really as a sensibility. The concept of the 'implied author' can be used to disrupt the idea that the meaning of texts can in any straight forward way be attributed to the experiences, values, beliefs of the person or

\footnotetext{
35 Wayne C Booth The Rhetoric of Fiction (Chicago: University of Chicago Press, 1961). See also his later re-statement of the value of this approach, 'Resurrection of the Implied Author: Why Bother?' in James Phelan and Peter Rabinowitz A Companion to Narrative Theory (Blackwell, Oxford, 2005). See also discussion in H. Porter Abbott The Cambridge Introduction to Narrative (Cambridge University Press, 2002). As I was finishing the final draft of this essay I discovered Lori Burn's use of similar terms drawn from Seymour Chatman (implied author, narrator, narratee, implied reader) 'Vocal Authority and Listener Engagement' in Mark Spicer and John Covach (eds) Sounding Out Pop: Analytical Essays in Popular Music (University of Michigan Press, 2010), 154-186.

${ }^{36}$ Abbott The Cambridge Introduction to Narrative, 77.
} 
people named as author on the credits (even though the threads do lead towards one or more real people).

Taking a further step, a distinction (again drawing from Booth) can also be made between the 'implied author' and narrator, the one who tells the story or specific parts of the story. A novel may be narrated in the first person ('I was arriving at the station...') or third person ('She was arriving at the station...') and less frequently in the second person ('You were arriving at the station ...'). In a similar way, a song may be narrated in the first person; it's happening or happened to me: 'I remember the thirty-five sweet goodbyes', 'yesterday, all my troubles seemed so far away'. Or, a song may be narrated in the third person singular: 'He's a rebel', or third person plural 'All the authorities, they just stand around and boast'.

Unlike many narrative forms, songs regularly address the listener in the second person. ${ }^{37}$ This is unusual in novels, and relatively rare in film and drama (apart from when the camera mediates the dialogue between characters). This is in part because popular songs draw from an oral tradition of directly addressing an audience (you - singular and plural) and because songs make extensive use of vernacular speech whereby the casual use of the second person 'you' is substituted for 'I,' deliberately or coincidentally implicating the listener. Interviews with songwriters, and scholarly studies, make it clear that songs are written and sung with an awareness that listeners often identify with the 'you' in phrases such as 'I love you' or 'you really got me' (she / he is singing to me), a staple of the love song. 38

But, the 'you' is not always an unnamed loved one. In his scornful and indignant song of betrayed trust Bob Dylan opens 'Positively 4th Street' (1965) with the line 'You've got a lot of nerve to call yourself my friend, when I was down you just stood there grinning'. The narrator goes on to recount the various ways that this unnamed 'you' has let him down. In 1981 Mark Booth wrote that this song has 'surely found no guilty listener who identifies with the addressee.'39 15 years later Simon Frith agreed: 'I think it would be impossible to read Bob Dylan's 'Positively 4th Street' as if we were the 'you' at issue'. 40 Both writers are in agreement: A listener would not hear the 'you' in this song as addressed to him or her; 'we' can identify with the singer because it allows us to articulate similar feelings of disappointment that we might have experienced. We are with the singer, that is our point of view, directed at our own 'you'.

${ }^{37}$ In 2010 a British newspaper produced a summary of the most recurrent words in all the Beatles recorded songs. The most frequent word is 'you' (occurring 2262 times), followed by 'I' (1736 times), the two words often featuring together in that perennial romantic trope of the pop song - 'I love you'. 'Beatles lyrics and the words they used most', The Guardian online, http://www.guardian.co.uk/music/datablog/2010/nov/16/beatles-lyrics-words-musicitunes accessed 6 June 2011.

38 For a discussion of this issue see Tim Murphy 'The When, Where, and Who of Pop Lyrics: The Listener's Prerogative' Popular Music, 8, 2, 1989, 185-193.

39 Mark Booth The Experience of Songs (New Haven: Yale University Press, 1981), 17.

40 Simon Frith Performing Rites, On the Value of Popular Music (Oxford: Oxford University Press, 1996), 184. 
Yet biographies and memoirs suggest that some people in Greenwich Village did interpret the song as directed at them. West 4th Street is where Dylan had first played at Gerde's Folk City, where he had lived in an apartment and where he had met Joan Baez. The song is a 'valedictory to the Greenwich Village scene' and many people, including Izzy Young who ran a folklore centre in Greenwich Village and Irwin Silber founder and editor of Sing Out! magazine, thought that it was directed at them personally. ${ }^{41}$ Dylan may have been vague in the 'you' he used in the song lyric. But he gave the song a title that clearly located his rage in a particular geographical location - 4th Street. The song lyric may not be specific ('you' and 'me'). It is the title that contains the sting.

The use of personal pronouns is just one aspect of the rhetorical art of the song, a quality that Frith has emphasized and which both Booth and David Lodge have highlighted in their writings about novels and literary fiction. Through personal pronouns - 'I', 'you', 'him', 'us', 'them' - character traits can be conveyed in an economical manner, allowing for the blend of precision and vagueness that is found in 'Positively 4th Street.'

Like novels, all songs contain characters. The characters maybe types or stereotypes - the home loving or fallen woman; the male outlaw or rambling man - both types a feature of country, blues and rock. The narrator may be the central character or might be commenting on, or in dialogue with other characters within a song. In 'Leader of the Pack' recorded by the Shangri-Las (1964), the narrator Betty is wearing Jimmy's ring, and in dialogue with her friends. She tells of her love for Jimmy (the leader of a motorbike gang), refers to her parent's disapproval and narrates Jimmy's eventual dramatic death from a motorbike accident.

Pop songs are populated with striking iconic figures such as 'Johnny B Goode' (1958), Chuck Berry's poor country boy who could play a guitar 'like a ringing bell' and who is destined for fame; Syd Barrett's cross dressing 'Arnold Layne' (1967) whose 'hobby' of stealing women's clothes from washing lines gets him arrested; the Beatles' miserly 'Mean Mr Mustard' (1969) and violent Maxwell Edison of 'Maxwell's Silver Hammer' (1969); Dolly Parton's 'Jolene' (1974), the flirtatious, attractive rival for her man's attentions; Walter Becker's and Donald Fagen's 'Kid Charlemagne' (1976), the underground chemist who supplies LSD to the counter culture and who is arrested when his car breaks down; Rubén Blades 'Pedro Navaja' ('Peter the Knife') (1978) a character taken by surprised and shot as he assails a women in possession of a Smith and Wesson 38 Special - a song set in New York's Latin barrio and which pays homage to Bertolt Brecht and Kurt Weill's 'Ballad of Mack the Knife' (1928); David Bowie's otherworldly Ziggy Stardust (1972) and disturbed, decadent Aladdin Sane (1973); Speech's (Todd Thomas) 'Mr Wendal' (1992) a wise homeless man befriended by the narrator; or Eminem's (Marshall Mathers) scurrilous 'Real Slim Shady' (2000).

In contrast, characterisation in popular songs may be implied, intimated and impressionistic, as exemplified in the songs of REM and Neko Case. The latter's 'People Got a Lotta Nerve' (2008) follows the real author's practice of deliberately composing ambiguous lyrics, and might (or might not) be heard as a tale narrated from the perspective of an animal exploited by humans, whilst playing with the clichéd idea of

41 David Hajdu Positively 4th Street: the Lives and Times of Bob Dylan, Joan Baez, Mimi Baez Fariña and Richard Fariña (London; Bloomsbury, 2001), 279. 
woman as man-eater. ${ }^{42}$ The characters in pop songs are signalled from the properties that can be heard (the words used, actions, names, musical arrangement - the qualities of the 'I' or 'you') and from that which can be inferred (the traits that may be implied through allegory and metaphor). ${ }^{43}$

Whilst the distinctions between implied author, narrator and character are relatively straight forward in the study of literary fiction, when it comes to songs, the sensibility imputed to the implied author, and the identity of the narrator, and the attributes of characters that appear in the song cannot be isolated from the public persona or star image of the songwriter or singer. ${ }^{44}$ This is not only the case for songwriters that sing their own compositions, but when a song is created deliberately to contribute to the persona of a singer - whether Paul Anka's re-writing of 'Comme d'Habitude' into 'My Way' (1969) as an anthem of individual achievement against adversity specifically for Frank Sinatra; or the 20 or so credited male songwriters/ producers that contributed the tracks to Rihanna's album Rated $R$ (2009). When Ann Powers reviewed this album for the Los Angeles Times she referred to its release after a widely publicised domestic assault by singer Chris Brown, and described it as 'a complex and fascinating portrait of a young woman's emotional process after enduring abuse.' Powers heard songs that 'express the whole range of what an abused woman goes through' and called the album 'a portrait of lived experience that doesn't step back from what's hardest to admit.' Powers response was informed by stories in the media, and a belief in the expressivity of a singer able to channel authentic emotions into the songs and tracks composed for her by a team of male writers. ${ }^{45}$

When challenging other naïve quests for authenticity in the musicology of popular songs, Allan Moore has argued that what a vocalist presents in any song is a persona rather than an authentic expression of real person. ${ }^{46}$ Moore draws from Edward T Cone's work on the composer's 'voice' in Western art music, and develops the idea by considering how a persona is conveyed through lyric, vocal melody and accompaniment. For example, he cites the way Richard Thompson uses 'the obsessive repetition of the sequence Dm-BmGm-E' to 'amplify' his articulation of the 'disintegration of a relationship' in the song 'The

\footnotetext{
42 I am referring to ambiguity that is deliberately produced as part of a songwriting strategy, and not divergences of interpretation by listeners. As Allan Moore has noted; 'with many songs, ambiguity is only the result of unfamiliarity with idiom, and is thus dependent upon the nature of listeners' competence' 'The Persona-Environment Relation in Recorded Song' Music Theory Online 11, 4, 2005, 6.

43 I am also drawing here from David Lodge's arguments about fiction, and the way the identity of characters can be interpreted from their actions, attributes and speech. Lodge also writes: 'The naming of characters is always an important part of creating them ... in a novel names are never neutral' The Art of Fiction, (London: Penguin, 1992) 37.

44 There are certain authors whose 'star' presence deeply affects the interpretation of the characters in their work, and who actually play on this in their writings. Examples might include the way the 'characters' of Martin Amis and Paul Auster appear in their fictional writings. See also Joe Moran Star Authors: Literary Celebrity in America (London, Pluto Press, 2000).

45 Ann Powers 'Album Review: Rihana's 'Rated R' Los Angeles Times, November 23 2009, http://latimesblogs.latimes.com/music_blog/2009/11/album-review-rihannas-ratedr.html accessed 14 June 2011.

46 Allan F Moore Rock The Primary Text (Open University Press, 1992)
} 
Way That It Shows' ${ }^{47}$ Moore's argument is suggestive of how an implied author and fictional characterisation are conveyed through the interplay of melody and accompaniment, or voice and setting. Yet, it is not only in the song text that a persona is present.

Studies of popular music performance, notably Philip Auslander's work, allow for Moore's 'musical persona' to be extended to encompass all aspects of performance when 'musicians play for an audience'48, as does scholarship on stardom which stress how knowledge of a real author is mediated by their 'star image'. ${ }^{49}$ The star image and performing persona adds further complications to the way personal identity and textual meaning are created, particularly when the author's public identity is transparently mannered and studied as in Eminem, Elton John, Alice Cooper (initially the name of a band, and then the public persona of Vincent Furnier), Elvis Costello, Lady Gaga, David Bowie, Marilyn Manson and perhaps less obviously Bob Dylan - most of these could be thought of as invented characters, adopting various personas or a persona, singing songs about fictional characters. This then informs the authorship of songs, whether Stefani Germanotta is writing for 'herself' as Lady Gaga, or Max Martin writing for the Backstreet Boys, or Damon Albarn is writing for the 'fictional' band Gorillaz. ${ }^{50}$

These distinctions between different authorial identities can be explored further with reference to two relatively well-known songs written by Ray Davies and recorded by the Kinks - 'Village Green Preservation Society' and 'Lola'. In each case the real author is Ray Davies, one of the most critically acclaimed songwriters to have come to prominence during the early rock era of the 1960s. The songs are copyrighted to his name. The implied author is a particular sensibility that has been conveyed by the songs, not only lyrically, but also through instrumentation and vocals, along with melodies and arrangements that are frequently characterised by 'sing-a-longs that owe as much to family get-togethers as they do to the music hall tradition.' 51 The implied author of these songs may be heard as whimsical, bewildered, and doubtful - the views of a man who feels out of time and place, slightly estranged and 'not like everybody else' (a phrase used as the title of one of Ray Davies's songs). At the same time it is an authorial sensibility 'with a great capacity to sympathize with others', characterised by a concern with 'the contemporary individual's relationship with family, place, the past, national identity, technology, the state, and internal forces' along with 'the individual in various states of confusion and incompleteness. ${ }^{52}$

The song 'The Village Green Preservation Society' is the first track on the album The Kinks Are The Village Green Preservation Society, a themed 'concept album' released in 1968 that (as many commentators noted) represented a musical and lyrical contrast from the

47 Allan F. Moore 'The Persona-Environment Relation in Recorded Song' Music Theory Online 11, 4, 2005, 7.

48 Philip Auslander 'Musical Personae' The Drama Review 50, 1 (2006), 100-199; 102.

49 See Lee Marshall, Bob Dylan, The Never Ending Star (Cambridge: Polity, 2007) 7.

50 For a discussion of Gorillaz's authorship see Lars Eckstein 'Torpedoing the Authorship of Popular Music: a Reading of Gorillaz' 'Fell Good Inc.' Popular Music 28, 2, 2009, 239255.

${ }^{51}$ Andy Miller The Kinks Are The Village Green Preservation Society (Continuum; London, 2003), 19.

52 Thomas Kitts Ray Davies, Not Like Everybody Else (Routledge; New York, 2008), 252. 
contemporary realities of anti-Vietnam war protests, racial tensions, and revolutionary struggles on university campuses and colonial territories. It was also stylistically at odds with the way such conflicts were given sonic expression that year, in songs such as 'Street Fighting Man' by the Rolling Stones's and Jimi Hendrix's distorted and searing guitar textures on Electric Ladyland.

The narrator of the song adopts the voice of a conservative representative of the Village Green Preservation Society. Or more accurately, the song is sung in the first person plural - 'we are the village green preservation society' - as if it is an anthem, the song of this society. Such an address is not uncommon in popular songs, and implies a 'we' and an 'us'. In this case the 'we' and 'us' is relatively clear; it is a specific fictional society dedicated to 'preserving the old ways' and these views are being presented to listeners. The 'we' and 'us' of popular songs is frequently less precise. It may refer to two people in a relationship ('we don't talk anymore') or it can implicate the listener as 'us' deliberately or inadvertently provoking an assent or dissent, as in the refrain 'we don't need no education', or 'we are the world' which provoked Reebee Garofalo to respond 'if we are the world then how do we change it?'53 In this case 'we' are being asked to agree that the village green should be saved.

In commentary over many years, the album has been routinely characterised as a whimsical nostalgic paean for a lost England, wistfully evoking an idealised village, and with good reason: The title song asks God to save a list of such recognisably English entities as draught beer, strawberry jam, the George Cross, Mrs Mopp (a radio character), Sherlock Holmes, the 'English-speaking vernacular', china cups, Old Mother Riley (music hall act) and Tudor houses. Yet, the opening and closing line - the most repeated phrase of the recorded song, apart from the chorus - asks for Donald Duck, Vaudeville and Variety to be saved. This prompted Allan Moore to remark 'Even in the English village, the presence of safe American cultural heroes is accepted. ${ }^{54}$

However, the theatre style known as Vaudeville is also not characteristically English, having developed in North America, and the prominence given to Donald Duck is quite deliberate. ${ }^{55}$ It is both ironic (fully cognisant of its incongruence with an English village green) and comic, suggesting a Disneyesque village green - a green that might appear in cartoons, or the caricature of a village green that may be pastiched at a Disney World or Disneyland. Yet, the song's cartoon surface is undercut by a more profound and pessimistic sensibility. 'The Village Green Preservation Society' draws from a neopastoral tradition of music, poetry and fiction in which the anxieties about the present (urbanisation, rational town planning, modernist architecture, state bureaucracy and surveillance) are resolved through a retreat into an idealised pastoral simplicity; an

53 The first being the well known refrain in Roger Waters' 'Another Brick in the Wall' (1979) as recorded by Pink Floyd; the second being a song composed by Michael Jackson and Lionel Ritchie which provoked Reebee Garofalo to respond 'if we are the world then how do we change it?'Reebee Garofalo 'Understanding Mega Events: If We Are The World Then How Do We Change It?' in R Garofalo (ed) Rockin' the Boat: Music and Mass Movements (Boston: South End Press, 1992).

54 Allan Moore Rock, The Primary Text, 101.

55 Kitts details the considerable time and effort that Davies has devoted to drafting and redrafting his lyrics. Ray Davies, Not Like Everybody Else. 
enduring aesthetic legacy, traced by Raymond Williams, in which 'the peace of country life' is contrasted with 'the political chaos of the cities.' 56

Musically the song is based on a straightforward repeating strophic sequence of three chords $(C, G, F)$. The voicing of $G$ and $F$ in the first inversion contributes a sense of unrootedness (or a search for roots in the village). The melody runs in easy to sing diatonic steps up and down the scale - the quality of an anthem that ordinary people can sing along with. The song's ordinariness, and its sense of irony, is also signalled by a 'truck driver's gear change', modulating upwards a tone to D, a trick that is corny, overfamiliar and very much a nod and wink towards vaudeville and variety; 'a painfully predictable show of amateur dramatics ... a cheap, tacky way of generating artificial momentum' according to Dominic Pedler. ${ }^{57}$

In contrast to this sunny kitsch pastoral, 'Lola' (1970) is a song of the nocturnal city, opening with reverb laden, lightly distorted, sardonic guitar chords ascending $\mathrm{C}, \mathrm{D}$ to the song's key of E, as we enter a London Soho bar where the champagne 'tastes just like Coca Cola', instantly locating the action in a sleazy part of town far from the innocence of the village green. The first person narrator is a man, confused about gender, sexuality and desire, recounting an encounter with a transsexual or a transvestite, ambivalent as to whether it is a pleasurable experience, embracing an anxiety and confusion that is, again, far from the ethos of the village green. It is a camp rock ballad that 'taps into the energy of a rich history in England and Europe of cross-dressing both for subversive purposes and for fun.'58 It is again strophic, using simple triads (E, A, D) and a sing-along melody that deploys a familiar 'la la la la la' refrain ('la la la la Lola') again evoking audience participation in a sing-along.

The real author of both songs is Ray Davies. I do not need to make any assumptions about the life, beliefs, experiences and values of the real author - although there are plenty of interviews, autobiographical and biographical writings about the life of Ray Davies and his songwriting intentions. The implied author can be interpreted from the songs, the particular selection of lyrical imagery, the use of a specific stylistic codes, drawing on distinct genre codes from folk, pop, rock, country and music hall, along with melodic shapes that are easily singable, and the adoption of an ordinary, untrained voice, somewhat thin and fragile, that conveys a degree of vulnerability. The implied author the sensibility that presents these fictional worlds - is one that uses wry humour and satire to undercut sentimentality, deploying irony and incongruity - qualities identified in Thomas Kitts insightful study of Ray Davies. ${ }^{59}$ The implied author refers to very specific details - foods (jam), drinks (Coca Cola), names (Desperate Dan), places (Soho). Yet, the implied author of 'The Village Green Preservation Society' holds contrasting social and political views to those of the implied author of 'Lola'. The narrators are equally contrasting characters, framed by sharply sketched lyrical and musical personae in the songs. Depending on our prior knowledge, we may also hear the star persona; we may comprehend these two songs as part of a body of work containing many other characters and narrators. We may also hear them as expressions or constructions of a star identity:

56 Raymond Williams The Country and the City (London; Hogarth Press), 17.

57 Dominic Pedler 'The Truck Driver's Gear Change: A Muso's Introduction', http://www.gearchange.org/muso_intro.asp accessed 14 June 2011.

58 Kitts Ray Davies, Not Like Everybody Else, 98

${ }^{59}$ Kitts Ray Davies, Not Like Everybody Else. 
A persona adopted by Ray Davies as a means of publicly commenting on mores, behaviours, habits and routines. We may have no way of knowing whether this is what he - the 'real' author - may or may not believe, or whether he has changed his views and ideas since recording the songs.

Much criticism evades these distinctions and tensions, assuming a consonance between the real author, the star image and the character in the song, supposing that the real Ray Davies has created songs that have revealed true details of his beliefs, life and experience. This is a point noted by Matthew Gelbart in his study of how Davies created a distinct 'persona and voice'; 'critical reception has tended to be preoccupied with attempting to figure out what the 'real' Ray Davies thinks'.60 Kitts, for example, has argued that the characters of Davies songs are 'extensions of his psyche' - a claim that is impossible to verify and not really necessary when understanding the songs. Yet, this type of argument is common when it comes to the relationship between song and its author - a continual quest to find the 'real person' behind the star image, to link the sentiments of the song to the singer and songwriter. Arguably this is an issue in all fictions, although songs and musicians seem more prone to literal interpretations than the work of novelists and filmmakers. The songwriter and singer Richard Thompson once remarked 'there should be a note on album sleeves making it clear that these songs have no relation to any person living or dead.' 61

An alternative critical response is to argue that there is no real musician lurking behind any words and images. This is Lee Marshall's stance in his study of Bob Dylan; 'while what we see may suggest to us a reality to which we do not have access ... what we see is all there is'. He argues that fans and critics spend too much effort searching for the 'real' person behind the star image, ignoring the way knowledge is shaped by 'what we see in front of us, not from anything backstage'. ${ }^{62} \mathrm{~A}$ similar, but more nuanced position, is developed by Frith in Performing Rites where he suggests that the tensions between real persona, 'star personality' and 'song personality' can be harmonised through performance in such a way that 'truth of feeling becomes an aesthetic truth, not a moral one'; pithily summed up in his claim that: "Sincerity" ... cannot be measured by searching for what lies behind the performance; if we are moved by a performer we are moved by what we immediately hear and see.'63

Yet, this position - that any truth and meaning resides in the performance persona or star image - ignores the way that knowledge of the real author informs interpretations of the personae. There is something behind and backstage, no matter how inaccessible to the curious fan. I see no reason why we cannot retain a sense of both real author and

60 Matthew Gelbart 'Persona and Voice in the Kinks' Songs of the Late 1960s' Journal of the Royal Musical Association 128, 2003, 200-241, 201.

61 Quoted in David Hepworth and Mark Ellen 'What Are Words Worth?' Word, 24, 2005, 70-89, 75.

62 Lee Marshall Bob Dylan, The Never Ending Star, 38, 41.

63 Simon Frith Performing Rites, On the Value of Popular Music, 215. In Frith's discussion of the performance of popular music he writes of the 'real person' as 'what we like to imagine they are really like, what is revealed, in the end, by their voice' (199). There is a greater sense uncertainty conveyed in Frith's formulation than I read in Auslander's use of Frith's work in his theory of performance, although both make the point that the real person is performed (and not revealed or exposed). 
performing persona, without romantically reducing one to an expression of the other, or eradicating the real person by assuming a postmodern collapsing of the real and its representation. To return to Richard Thompson's reflections: 'The biggest misunderstanding is people assuming that you're writing about your own life. It's really much more oblique than that - it's mediated reality.' ${ }^{64}$

As Thompson implies, there are mediations between the real author, the song and a performance. In authoring and presenting songs to the public musicians are continually negotiating and often quite deliberately seeking to conflate or contest the distinctions between on stage/ off stage, public/ private, artist/ art work, documentary/ drama and real/ imaginary. It may be futile to peer behind at the moment of performance, but there is much to explore in the activities and the mediations of authors that precede and then connect with the persona in performance. The categories of real author, implied author, character and narrator, and (star) persona can be used to question and to unbundle the presumed connections between author and song, and equally to question the claim that there is nothing more than a performing persona: To allow for a critical discussion of how values, beliefs, world views and experiences are created, represented, conveyed and mediated through songs without being reduced to the authentic experience or coherent beliefs of the songwriter or singer, or reduced to the surface appearance of a performance.

These categories also allow for an exploration of how musicians negotiate such tensions. For example, since the 1960s a type of singer-songwriter, adopting a 'confessional', acoustic and intimate style of delivery has often sought to blur such distinctions, placing an emphasis on the autobiographical and personal relationships as a way of providing 'a microcosmic insight into the politics of love and hate which had earlier characterised folk protest' ${ }^{65}$ Profoundly influential here has been Joni Mitchell, and particularly the album Blue (1971), with its sparse acoustic guitar and piano textures and conversational delivery of highly personal lyrics seemingly providing 'a window into her subjective universe'. 66

Yet, this intimate personal world has been consciously constructed by the songwriter, not only through the selection of lyrical imagery, but also through the adoption of specific production techniques. As Nicola Dibben has argued, the creation of an ambience of intimacy is dependent upon 'the amount of reflected sound, and relative loudness of sounds within the mix.'67 Not only does the sense of intimacy depend on production practices and aesthetic choices it also entails an ideological commitment, as Whiteley notes, 'an investigation into the biographical, rather than the ideological, context of truth'. ${ }^{68}$ Performers influenced by Joni Mitchell (such as Tori Amos, Fiona Apple and Sinéad O'Connor) have encouraged the listener to hear the collapsing of such categories;

64 Bill Flanagan, Written in My Soul (Chicago; Contemporary Books, 1987), 223.

65 Sheila Whiteley Women and Popular Music: Sexuality, Identity and Subjectivity (London, Routledge,2000), 75.

66 Sheila Whiteley Women and Popular Music 78

67 Nicola Dibben 'Vocal Performance and the Projection of Emotional Authenticity' in Derek Scott (ed) The Ashgate Research Companion to Popular Musicology (Farnham: Ashgate, 2009), 317-333.

68 Sheila Whiteley Women and Popular Music 75 
to hear the real person exposed, revealed in the narrator of the song, seemingly with no critical distance between the real author, implied author and persona.

Such a style may be may be heard as naïve and sentimental, solipsistic even, placing the unified, naturalised, free 'bourgeois' subject at centre of the world. Charlotte Greig comes close to this view when she describes Joni Mitchell as 'narcissism and self-indulgence personified.' 69 The category of confessional songs has also been criticised by Lori Burns and Mélisse Lafrance in a discussion of Tori Amos: 'By constantly framing Amos's music as personal in nature, her critics irresponsibly ignore the social context from which her experiences emerged'. Burns and Lafrance advance a more general claim that the label of 'confessional' songs 'due to its inevitable association with guilt, apology, and sin ... appears to be reserved primarily for female artists, a reservation that implicitly reproduces the Christian/male supremacists notions of woman-as-already-fallen'. ${ }^{70}$

Yet, it can be countered that this is a reductive caricature of the confessional aesthetic; songwriters are by no means such passive or complicit victims of an oppressive aesthetic ideology. Whilst it may be influenced by the Catholic confessional, it also has roots in radical folk protest, and a type of 'confessional poetry', named by critics in the late 1950s, but sometimes traced back to Walt Whitman. ${ }^{71}$ It is also not the sole preserve of women. Lennon's post-Beatles songs on the albums Plastic Ono Band (1970), Imagine (1971) and Mind Games (1973) have regularly been described as confessional, and evidence suggests that they were a quite deliberate aesthetic strategy whereby the real author sought to challenge the fab mop-top Beatle star persona. The 'confessional' songs and performances of these and other musicians do not necessarily need to be viewed as detached from social context. Instead they might be interpreted as providing an expressive critique of the industrial, commercial systems that have allowed for the commodified fragmentation and alienation of the real person, the persona and character. It is certainly possible to interpret O'Connor's and Mitchell's songs, and Lennon's immediate post-Beatles songs in such a way. These songwriters might be viewed as engaged in a Romantic challenge which seeks to resolve the tensions between the real author, implied author, narrator and star image, and recover the fragmented self through an aesthetic that consciously seeks to dissolve such distinctions, engaged in a sociological or political as well as a subjective and stylistic struggle.

The blurring of these distinctions can also be heard in much rap in which there is a frequent struggle to assert the importance of social context by 'being real' to the life style being portrayed. ${ }^{72}$ Perhaps less obviously this blurring has also been a feature of chart pop in the UK in the twenty first century. Lily Allen, for example, has been both celebrated and castigated for her candid commentaries on celebrity culture and the changing

69 Charlotte Greig 'Female Identity and the Woman Songwriter' in Sheila Whiteley (ed) Sexing the Groove: Popular Music and Gender (London; Routledge, 1997), 168-77, 174.

70 Lori Burns and Mélisse Lafrance Disruptive Divas: Feminism, Identity and Popular Music (London: Routledge, 2002), 64.

71 See M. L. Rosenthal 'Robert Lowell and the Poetry of Confession' in The Modern Poets: A Critical Introduction (New York: Oxford University Press, 1960), 225-244. See also David Graham and Kate Sontag (eds) After Confession: Poetry as Autobiography (Saint Paul: Graywolf Press, 2002).

72 See Jeff Chang Can't Stop, Won't Stop: A History of the Hip-Hop Generation (London; Ebury Press, 2005). 
experiences of young women. Sia Michel in The New York Times declared that her songs 'capture a sense of universal teenage angst with her cinematic tales of bad breakups, club spats and backstabbing friends. She symbolizes a new blogging-age, middle-class girl; cockily ambitious, sceptical yet enthusiastic, technically savvy, musically open, obsessed with public expression and ready to fight back.' ${ }^{73}$ Much of this is evident in Allen's 'The Fear' (2009), co-authored with Greg Kurstin, and awarded an Ivor Novello by the British Academy of Songwriters, Composers and Authors. A conventional pop song, with a light and airy synth-pop arrangement, narrated in the first person in a deceptively easy conversational voice, it tells of a young woman's unscrupulous desire to become rich and famous by exploiting her own body (taking her clothes off for tabloid newspapers), seeking fast cars, diamonds and 'massive consumption'. Yet, as Michel observes of Allen's songs in general, 'darkness lurks below every cheery surface', and it is apparent here as this song moves to a more melancholic chorus in which the narrator's voice becomes multi-tracked, echoey and more distant and no longer certain what is 'right and real' or what she's 'meant to feel anymore', until she is 'taken over by the fear.'

The song generated considerable discussion about whether the narrator was the real author singing from direct personal experience, exposing her anxieties, reflecting upon past actions with a sense of mild shame, 'a real person telling us the most intimate details of her real life'74, comparable to Powers interpretation of Rihanna. Or whether it was narrated in the first person by a character - 'a piece of persona projection ... in which she shaped selected aspects of her character and autobiography into songs that would ring a bell with ordinary young women and the men who want to go to bed with them.' ${ }^{75}$ Whilst the celebrity status of performers of rap and chart pop means that they are often required to authenticate themselves in exaggerated ways, when compared with the singer songwriter, ${ }^{76}$ the different categories of authorship can be used to explore how their authorship is presented and critically mediated by journalists.

In contrast to the blurring of real author, implied author, character and persona, performers such as Kate Bush, Laurie Anderson, the Pet Shop Boys, Steely Dan, Tom Waits, Randy Newman, Lady Gaga quite consciously craft a critical distance and open up spaces between these categories. This may be achieved through irony, camp and artifice, satire, studied understatement, mannered indifference, or unsubtle exaggeration when presenting characters, whether in the first, second or third person.

For example, Steely Dan (comprised of songwriters Donald Fagen and Walter Becker) use music, lyrics, song structures and arrangements to disrupt any assumption of a correspondence between real and implied author, character and persona. Walter Everett has highlighted the band's harmonic preference for seventh, ninth, eleventh and

73 Sia Michel 'Lily Allen, Britain's New Pop Star, Has Cheek, and Bite, to Spare' New York Times, 5 August 2006 http://www.nytimes.com/2006/08/05/arts/music/05alle.html accessed 17 May 2011.

74 Neil McCormick 'Lily Allen - It's Not Me, It's You: Pop CD of the week review' The Daily Telegraph, 22 January 2009 -

http://www.telegraph.co.uk/culture/culturecritics/neilmccormick/4317076/Lily-AllenIts-Not-Me-Its-You-Pop-CD-of-the-week-review.html accessed 17 June 2011.

75 Robert Christgau 'Lily Allen: The Same Everygirl After All' Barnes \& Noble, 16 February 2009 - http://www.robertchristgau.com/xg/bn/2009-02.php accessed 19 May 2011.

76 Moore 'Authenticity as Authentication' 
thirteenth chords and the rarity of 'unadorned, unambiguous and naïve triads'77. A characteristic of Steely Dan has been their extensive use of what has come to be called, somewhat wryly, by the songwriters the $\mu$ major or 'moo' or 'mu' chord. This is a major chord with an added second (or added 9th) which is voiced to de-emphasize the third (frequently voiced as $1,5,9,10$, often with the 3 in the bass) ${ }^{78}$. Fagen has also remarked upon how the vocal melodies of their songs are 'derived more instrumentally' rather than created as independent sung melodies - a characteristic that means that they are not easily memorable or singable without the 'chordal background.'79 There is no attempt to use singable melodies to draw the listener into the narrator's world. Becker's and Fagen's songs are constructed so that harmonies and voicing, along with shifts to chords and modulations that would be unexpected in conventional rock sequences, are used to enhance, undermine and extend lyrical content - transforming the sentiment of a banal turn of phrase into allusions altogether more profound, edgy, elusive or odd; inflecting lyrics with sinister, unsettling or anxious overtones; undermining the expected and familiar.

This musical orientation is fused with wry, ironic and even cynical lyrics in which, as Everett has also pointed out, the songwriters repeatedly have their narrators characterising the world and behaviour of others through sarcasm, hyperbole and litotes. Their lyrics are influenced by so-called 'black humorists' such as John Barth, Joseph Heller, Terry Southern, and dystopian science fiction (the two strands blended in Kurt Vonnegut, a notable influence). Fagen recalled that 'we were after a theatrical effect, the friction produced by the mix of the music and the irony of the lyrics' 80 The songs are populated by narrators who are romantic loners or dreamers, outsiders or on the margins, often male losers of some kind. Although most songs are sung in the first person, they are very clearly character studies, the songwriters uninterested in confessional, autobiographical songwriting. The songs use fastidiously crafted rhyming schemes with 'vowel sounds ... meticulously matched' often through assonance, simile and enjambment, a style that 'doesn't happen by accident, and testifies to Becker and Fagen's thoroughness in wringing every drop of syntactic intrigue from their mini-narratives.' 81

The songs are produced with an understanding of how recordings may be listened to hundreds of times; informing the inclusion of oblique musical and lyrical references that constitute a plethora of indulgent asides, footnotes, quotes, knowing nudges, puns and allusions (incorporating references to obscure jazz recordings, to literature, to events and characters); signifiers that may not be noticed until after repeated listening and the acquisition of considerable knowledge about the act. This blend of musical characteristics, lyrical concerns and attention to detail, presents a highly idiosyncratic

\footnotetext{
77 Everett, Walter 'A Royal Scam: The Abstruse and Ironic Bop-Rock Harmony of Steely Dan', Music Theory Spectrum, Vol 26 (2004) pp201-35, 205.

${ }^{78}$ For internet discussions of this chord and its appearance in various songs see www.steelydan.com/songbook.html 'Intro to the Steely Dan Songbook' (accessed 11 November 2009) and www.hakwright.co.uk/steelydan/mu-major.html 'Steely Dan, The Mu Major Chord' (accessed 11 November 2009).

79 Cited in Bruce Pollock and John Stix 'Steely Dan, Introduction' 2-3 Steely Dan Complete, Universal Music Publishing, Warner Brothers, Miami, 1995, 2.

80 Bruce Pollock and John Stix 'Steely Dan, Introduction'

81 Don Breithaupt Aja (London, Continuum), 38.
} 
'sensibility' and identity, one that offers no discernible personal or autobiographical point of identification, with no pretence that the real authors will be revealed.

A related approach, albeit without the crafted levels and layers, can be found in Randy Newman's habit of presenting concise blues inflected pop songs with 'unreliable narrators'; narrators whose sincerity, values or truthfulness may be open to question. The idea of the unreliable narrator (again introduced by Booth) is one that has quite consciously informed Newman's songs as he narrates in the first person from the perspective of a variety of characters that hold prejudiced or morally dubious viewpoints. As he told Zollo: 'I like untrustworthy narrators and things where the audience knows stuff that the narrator doesn't know.'82 Newman was once asked why he 'stepped out of character' in the song 'Rednecks' (1974) - a tale narrated from the perspective of a southern racist bigot - a viewpoint that is somewhat undermined when the narrating redneck abruptly starts to sympathetically pontificate about the plight of black people. Newman's response gives an insight into the way his songwriting craft is informed by a tacit if not an explicit awareness of these debates about authorship, narration and character:

It's just a mistake. The guy wouldn't know that. It's an error, on my part, as a writer. But I did it anyway. I knew it. You see, with that guy, everything's fine, he's insulted, he's a bigot, right? He's insulted by the fact that they humiliate his governor - the governor of a state of ten million people - on this TV show ... so the guy does this song, and the one thing wrong with it is he wouldn't know the names of all the ghettos, he wouldn't know Hough in Cleveland and all that stuff. So it is out of character, you're right, but it isn't me stepping in. It is me stepping in, but I knew it. Anyway, I knew I did it wrong. ${ }^{83}$

It might be countered that this slippage, rather than an error, makes the character in the song even more unreliable - and perhaps the representative of the Village Green Preservation Society is equally unreliable, and not to be trusted, for wishing to save Donald Duck.

There are many other songwriters (like Newman, or Becker and Fagen), acutely aware of the slippages that can occur, and the spaces that can open up, between the real author, implied author, narrator, character and star persona. They may attempt to use contextual or 'paratextual' information to influence the way their songs are interpreted in these terms. This may entail speaking in interviews, writing liner notes, addressing an audience at a concert in a manner that attempts to clarify the meaning of a song. Or the interview may be used to obfuscate, a tactic routinely used by Tom Waits who once remarked 'I usually try to bury anything autobiographical.'84 As Polly Harvey responded to an interviewer who told her that many of her songs had been 'written specifically from your point of view':

Well, I disagree with you there entirely. I'm not interested in telling people my autobiography. ... something I've always done, and I've talked about this till I'm blue

82 Paul Zollo Songwriters on Songwriting, Fourth Edition (New York: Da Capo Press, 2003) 269

83 Zollo Songwriters on Songwriting 271

${ }^{84}$ Quoted in Bill Flanagan Written in My Soul 388. 
in the face, is adopt the techniques a writer would adopt, which is to assume different narratives - third person, first person, dramatic monologue, casting myself as a man or as a woman - as a way of exploring ideas and characters. In that way, I'm no different from any novelist or any poet, or any other songwriter. ${ }^{85}$

An encounter with a critic that confirms that the author is far from dead, and that authorship and the pop song is rarely straightforward.

\section{Epilogue: unbundling the author}

The idea that the self, self-knowledge and personal identity may only be known as a bundle of attributes, experiences and beliefs and that these may be neither coherent nor complete is a theory that has often cropped up in philosophical debates. It can be traced back to philosopher David Hume's suggestion (first published 1739-40) that the mind is a bundle of perceptions. ${ }^{86}$ John Perry has more recently taken up this theme and written of the self as a 'bundle of cognitive complexes' characterised by 'a constant activity of trying to maintain coherence and order' ${ }^{87}$ Such a notion resonates with an awareness of apparent contradictions or paradoxes in our ordinary behaviour, beliefs and attitudes towards others. Perry's version of bundle theory - a competing 'bundle of bundles' is drawn from philosophical reflections upon his personal experiences along with observations of the lives of others; varied situations in which behaviour and world views often appear to be incoherent and contradictory, yet still attributable to one 'self'. ${ }^{8}$ I find this suggestive of the apparent paradoxes and inconsistencies that may be found in the activities, work and performances of songwriters and musical authors - contradictions that should not be treated as problems to be resolved, but enigmas to be interrogated.

There are two other salient ways in which the notion of a bundle of qualities, attributes and behaviours resonates in popular music culture. First, is the commercial contract which defines a recording artist signed to a music company as a 'bundle of rights' through which the corporation exploits their legal right to use the image on a T-shirt; music in a game, advert, film or public place; writings in a magazine; voiceover on radio; lyrics in a songbook and so on. An artist's management may assign these rights to one company, or they may license the use of various aspects of an artist's creative work across businesses divided by geographical territory.

Whilst copyright may be used to police the influences on songwriting (on behalf of individuals rather than groups of people or traditions), it has increasingly allowed the unbundling of the self as a condition of cultural production. As Rosemary Coombe has argued:

85 James Medd 'What You Say is Powerful, Claims Polly Harvey, What You 'Imply' Even More So' Word, 100, June 2011, 22-23, 22.

86 David Hume A Treatise of Human Nature (London: Penguin, 2004).

87 John Perry 'Selves and Self-Concepts' in Joseph Keim Campbell, Michael 0’Rourke and Harry Silverstein (eds) Time and Identity (MIT Press: Cambridge, Mass), 229-247, $244 / 246$.

88 See discussion of this in Matthew H. Slater 'Introduction: Framing the Problems of Time and Identity' in Joseph Keim Campbell, Michael O'Rourke and Harry Silverstein (eds) Time and Identity (MIT Press: Cambridge, Mass), 1-24. 
Various components of an individual's persona may be independently licensed ... A celebrity could, theoretically at least, license her signature for use on fashion scarves, grant exclusive rights to reproduce her face to a perfume manufacturer, voice to a charitable organisation, legs to a pantyhose company, particular publicity stills for distribution as posters and postcards, and continue to market her services as a singer, actress, and composer. The human persona is capable of almost infinite commodification, because exclusive, nonexclusive, and temporally, spatially, and functionally limited licenses may be granted for use of any valuable aspect of the celebrity's public presence'. 89

The disaggregation of the public persona has increased at the same time that the conceptual understanding and commercial management of an artists' repertoire of songs has shifted from being thought of in terms of singles and albums to bundled and unbundled - one of the consequences of the digitalization of recording and digital downloading. Pink Floyd successful took EMI to court to stop the company unbundling the album Dark Side of the Moon (1973) winning the argument that this is an entire art work and must be sold and purchased complete rather than as a series of discrete, individual tracks (although they quietly allowed the album to be unbundled a year later). In contrast, when the Beatles back catalogue was eventually made available for digital download it was made accessible unbundled - meaning that the hugely influential and critically acclaimed albums Sgt Pepper's Lonely Hearts Club Band (1967) and Abbey Road (1969) - originally containing 'suites' of songs segueing into each other - could be purchased as isolated tracks, the albums broken up into abstracted, decontextualised, sometimes incomplete sounding or abruptly ending tracks, for shuffling or re-sequencing at the consumers will and whim (much to the consternation of some rock critics).

If musicians can unbundle the component parts of their public personas and their album repertoire (as individuals may think of their personal self as a bundle of identities), I will conclude by suggesting that we (critics, musicologists, scholars) can also unbundle the idea of the author - and perhaps with similar mixed consequences and anxieties. We can ask how and in what ways the various components that make up an author's activities and identities are conceived, constituted, combined and communicated. This would entail retaining an awareness of the range of perspectives that I have surveyed in this essay. From music criticism and musicology we can draw on the fact that there is, in most cases we encounter, a real author with intentions, beliefs and a set of ethical and musical values that they wish to convey to listeners. This can be researched and verified according to information that is available about living and dead songwriters or composers (and certainly not naively assumed or read from texts). Comprehension of the real author can proceed with an awareness of the equally real world in which there is both partial knowledge and an excess of information about the struggles for critical recognition and commercial reward, along with the social circumstances within which creativity is realised in relation to genre worlds, legal frameworks and various material constraints.

The approach that I am advocating here does not see the author disappear under sociological power struggles and critical interpretations, but neither is the author treated as a transcendent touchstone. The author produces and inhabits personas that are both

${ }^{89}$ Rosemary Coombe The Cultural Life of Intellectual Properties (Duke University Press, 1998) 91. 
musical and social, and the bundled or unbundled texts and identities (implied authors, characters, narrators, personas, star images) can provide various insights into the material and ideological struggles through which popular songs are made and mediated. The unbundled author cannot be explained reductively through models of sociological fields, cannot be contained by the multiple or monological interpretations of critics, and cannot be condensed into biographical tales willed by great individuals.

\begin{abstract}
Within the broad field of musicology and music criticism the author as creative originator and authority remains a central figure. Yet sociologists have been sceptical of the emphasis placed on authorship in the arts and humanities, and argued that creativity, artworks and artistic reputations are produced through social processes and struggles. Meanwhile, a strand of cultural theory has followed Barthes' pronouncement of 'the death of the author' and deemed authorship irrelevant to critical debate about meaning and value. In this article I advocate an intermediate or mediating approach, attuned to the insights from both musicology and sociology, and suggest ways that concepts drawn from the study of fictional narrative can be used to 'unbundle' the author. Through this I open up a series of questions about how authorship is constructed, conveyed, communicated and contested through the mediations of pop songs and identities of songwriters.
\end{abstract}

